\title{
EGFR, but not COX-2, protein in resected pancreatic ductal adenocarcinoma is associated with poor survival
}

\author{
JOHAN BOURGHARDT FAGMAN ${ }^{1,2}$, DAVID LJUNGMAN ${ }^{1,2}$, PETER FALK $^{1,2}$, BRITT-MARIE IRESJÖ ${ }^{1,2}$, \\ CECILIA ENGSTRÖM $^{1,2}$, PETER NAREDI ${ }^{1,2}$ and KENT LUNDHOLM ${ }^{1,2}$ \\ ${ }^{1}$ Department of Surgery, Institute of Clinical Sciences, Sahlgrenska Academy, University of Gothenburg; \\ ${ }^{2}$ Department of Surgery, Sahlgrenska University Hospital, SE-413 45 Gothenburg, Sweden
}

Received October 31, 2018; Accepted February 19, 2019

DOI: $10.3892 / 01.2019 .10224$

\begin{abstract}
The effects of EGFR and COX-2 protein overexpression on clinical outcomes in pancreatic ductal adenocarcinoma (PDAC) patients remains unclear. Therefore, the aim of the present study was to evaluate the protein expression of epithelial growth factor receptor (EGFR) and cyclooxygenase-2 (COX-2) in tumor cells in surgically resected PDAC, in comparison with clinicopathological characteristics and clinical outcomes. Immunohistochemical staining of formalin-fixed paraffin-embedded tissue derived from surgically resected tumors was performed. Tissue slides were evaluated for membrane wild-type EGFR and cytoplasmic COX-2 staining using a histoscore system. Statistical associations between EGFR and COX-2 staining and clinicopathological characteristics were examined to predict survival. In a cohort of 32 resected PDAC patients, high EGFR protein expression in tumor cells was significantly associated with shorter median overall survival (7.9 vs. 39.2 months, $\mathrm{P}=0.0038)$. The corresponding hazard ratio $(\mathrm{HR})$ for patients with high EGFR protein expression in tumor cells was 3.12 [95\% confidence interval $(\mathrm{CI})$ : 1.39-7.00, $\mathrm{P}=0.006$ ]. COX-2 protein expression was not associated with survival (22.6 vs. 24.5 months $\mathrm{P}=0.60$; HR 1.22 95\% CI: 0.59-2.51, $\mathrm{P}=0.60$ ). Following multivariate Cox regression analysis, high EGFR protein expression in tumor cells $(\mathrm{P}=0.043)$ remained as significant independent prognostic factor for survival. In conclusion, high wild-type EGFR protein expression, but
\end{abstract}

Correspondence to: Dr Johan Bourghardt Fagman, Department of Surgery, Sahlgrenska University Hospital, Vita Stråket 12, paviljong plan 2, SE-413 45 Gothenburg, Sweden

E-mail: johan.bourghardt@gu.se

Abbreviations: PDAC, pancreatic ductal adenocarcinoma; EGFR, epithelial growth factor receptor; COX-2, cyclooxygenase-2; HR, hazard ratio; immunohistochemistry, IHC; TBS, tris-buffered saline; DAB, 3,3'-diaminobenzidine; H-score, histoscore; CI, confidence interval; OS, overall survival

Key words: EGFR, COX-2, survival, pancreatic cancer not COX-2 protein expression, in tumor cells is a prognostic factor for reduced overall survival following pancreatic tumor resection, supporting a role for EGFR in identifying resected patients that may benefit from EGFR-targeted therapy.

\section{Introduction}

For pancreatic ductal adenocarcinoma (PDAC), one of the deadliest malignant diseases $(1,2)$, there has been poor progress in the development of new effective treatments. Surgical resection is still to date the only potentially curative treatment. However, only about $20 \%$ of patients present tumors eligible for resection at time of diagnosis (1). Despite surgery, many patients relapse or develop metastasizing disease $(3,4)$. Hence, there is a need for therapy improvement and specific biomarkers that predict patient outcome or that can guide individualized treatment after surgery.

Epithelial growth factor receptor (EGFR) has been extensively studied in PDAC (5). EGFR protein overexpression has been reported in $40-70 \%$ of pancreatic cancers $(6,7)$, with variable association with survival (8). Erlotinib, a small molecule EGFR inhibitor, is in clinical use in combination with gemcitabine for unresectable locally advanced or metastatic PDAC $(9,10)$. The effectiveness of erlotinib in resected PDAC is less studied and remains unclear $(11,12)$. Recent experimental studies by Ardito et al (13) and Navas et al (14) showing that knock-out of Egfr in KRAS-mutated mice completely blocked development of PDAC, suggest a critical role for EGFR activation in the pathogenesis of human KRAS-driven PDAC.

Cyclooxygenase-2 (COX-2), far less studied than EGFR in PDAC, has also been reported to be overexpressed in 60 to $70 \%$ of tumor patients $(15,16)$. The association with survival is unclear (17-22). Further, no anti-COX-2 treatment has yet been proven effective in PDAC patients in combination with chemotherapy (23). Activation of COX-2 signaling has been reported to promote PDAC tumor growth in experimental models $(24,25)$.

EGFR and COX-2 signaling pathways have been suggested to be linked. This has been reported in experimental studies of colorectal cancer and head and neck cancer, where EGFR is shown to upregulate COX-2 or vice versa $(26,27)$. However, whether there is a link in human PDAC is currently unknown. 
The effects of EGFR and COX-2 protein overexpression on clinical outcomes in PDAC patients remain unclear. Therefore, the aim of this study was to explore the prognostic and clinicopathological significance of both EGFR and COX-2 protein expression in tumor cells in patients with surgically resected PDAC aimed at cure.

\section{Materials and methods}

Patients and tumor tissue samples. Pancreatic tumor tissue sections were obtained from 32 patients with pancreatic ductal adenocarcinoma who underwent surgical tumor resection in 1998 to 2005 at Sahlgrenska University Hospital, Gothenburg, Sweden. All patients underwent surgery as primary treatment and none had received neoadjuvant chemotherapy. The group of patients consisted of 53\% males and $47 \%$ females with a mean age of 64.1 years (range 50 to 80 years) at surgery. Median overall survival was 22.9 months (range 1.1 to 122.4 months) after surgery. All the tumors were histologically diagnosed as ductal adenocarcinoma and classified according to the TNM staging system by the Pathology department at Sahlgrenska University Hospital. The present study was approved by the Regional Ethical Review Board in Gothenburg, Sweden (reference number 002-06) and all participants gave written informed consent. Data was analyzed anonymously.

Histology and immunohistochemistry. Pancreatic tumor tissues were fixed in $10 \%$ neutral-buffered formalin and embedded in paraffin. Sections of $4 \mu \mathrm{m}$ were prepared. Immunohistochemistry (IHC) was performed as follows: After xylene deparaffinization, ethanol dehydration and antigen retrieval (water bath for $30 \mathrm{~min}$ at $98^{\circ} \mathrm{C}$ in citrate buffer $\mathrm{pH}$ 6.0), sections were first blocked with $5 \%$ non-fat milk in $5 \mathrm{mM}$ Tris-buffered saline (TBS), pH 7.8 for $30 \mathrm{~min}$ and then endogenous peroxidase activity was quenched in $0.3 \% \mathrm{H}_{2} \mathrm{O}_{2}$ solution (Dual Endogenous Enzyme Block, Dako Envision K4065, Agilent Technologies, Santa Clara, CA, USA) for $15 \mathrm{~min}$. Sections were incubated with primary antibodies diluted in 5\% non-fat milk in TBS overnight at $4^{\circ} \mathrm{C}$, followed by incubation with polymer labelled secondary antibodies conjugated with HRP (Labelled polymer-HRP, Dako Envision K4065, Agilent Technologies), for $40 \mathrm{~min}$ at room temperature. Bound peroxidase was visualized by 15 min incubation in a 3,3'-diaminobenzidine (DAB) solution (Dako Envision K4065, Agilent Technologies). Sections were washed, counterstained with hematoxylin, dehydrated and mounted. The following antibodies were used: Monoclonal mouse anti-human wild-type EGFR (detects the membranous N-terminal part of the extracellular domain, but not the 2-7 truncated EGFR variant (EGFR-vIII), immunizing peptide aa 30-198), clone DAK H1 WT, M7298, Agilent Technologies, dilution 1:50, polyclonal rabbit anti-COX-2 (cytosolic detection), ab15191, Abcam, Cambridge, UK, dilution 1:200, negative control mouse IgG1 (X0931, Agilent Technologies) and rabbit IgG1 (X0903, Agilent Technologies) diluted in 5\% non-fat milk in TBS. Negative control antibodies were diluted to the same protein concentration as the primary antibody. Methodology has been used and described previously $(28,29)$.
Scoring of immunohistochemical stainings. Tumor tissue samples were evaluated for membranous EGFR and cytoplasmic COX-2 staining using a histoscore (H-score) system. Staining intensity of EGFR and COX-2 protein expression was scored from negative $($ score $=0)$, low $($ score $=1)$, intermediate $($ score $=2)$ to high $($ score $=3)$. The percentage of tumor cells showing positive staining was assessed separately. For both staining intensity and percentage of tumor cells, 10 high magnification (x200) fields per patient and staining were assessed and averaged. The final staining score is the product of the average intensity score and the average percentage of tumor cells showing positive staining and ranged from 0 to 270 (30). Scoring of tumor tissue samples was performed in blinded manner by JBF without knowledge of pathological and clinical data. For statistical analysis, EGFR and COX-2 scores were classified into two staining grades according to the median staining score (the high grade represents $\geq$ median; the low grade represents < median).

Statistical analyses. Data are presented as median and range (continuous data), and as numbers and percentages (categorical data). Mann-Whitney U and Pearson's Chi-square tests were used to determine the association between EGFR and COX-2 protein expression in tumor cells and clinicopathological and molecular parameters. Overall survival (OS) was evaluated using Kaplan-Meier survival plots, and differences in survival were tested using log-rank (Mantel-Cox) tests. Cox proportional hazards regression analyses were used to estimate hazard ratios (HR) and 95\% confidence intervals (95\% CI). Multivariate Cox proportional hazards regression analysis was performed to assess independent prognostic factors using covariates found significant in univariate analysis (regional lymph node metastasis and EGFR score). All P-values corresponded to two-sided tests and $\mathrm{P}<0.05$ was considered to indicate a statistically significant difference. All statistical analyses were conducted using either SPSS version 22 (IBM Corp., Armonk, NY, USA) or GraphPad Prism 7 (GraphPad Software, Inc., La Jolla, CA, USA).

\section{Results}

Association between EGFR and COX-2 protein expression in tumor cells and clinicopathological characteristics. To assess EGFR and COX-2 protein expression in tumor cells in surgically resected pancreatic ductal adenocarcinoma (PDAC), protein expression level in PDAC samples was scored and divided into two subgroups: Low and high grade (Fig. 1) and was then compared to clinicopathological characteristics. In the study cohort, no significant associations of either EGFR or COX-2 protein expression in tumor cells were found with tumor location, tumor stage or regional lymph node metastasis (Tables I and II). However, we detected a weak positive correlation between EGFR and COX-2 protein expression in tumor cells (Spearman's rank correlation coefficient of 0.363 , $\mathrm{P}=0.041$, Fig. 2).

High EGFR protein expression in tumor cells associates with shorter overall survival in PDAC patients. In order to examine the prognostic impact of EGFR and COX-2 on survival outcome, we analyzed overall survival (OS) time 


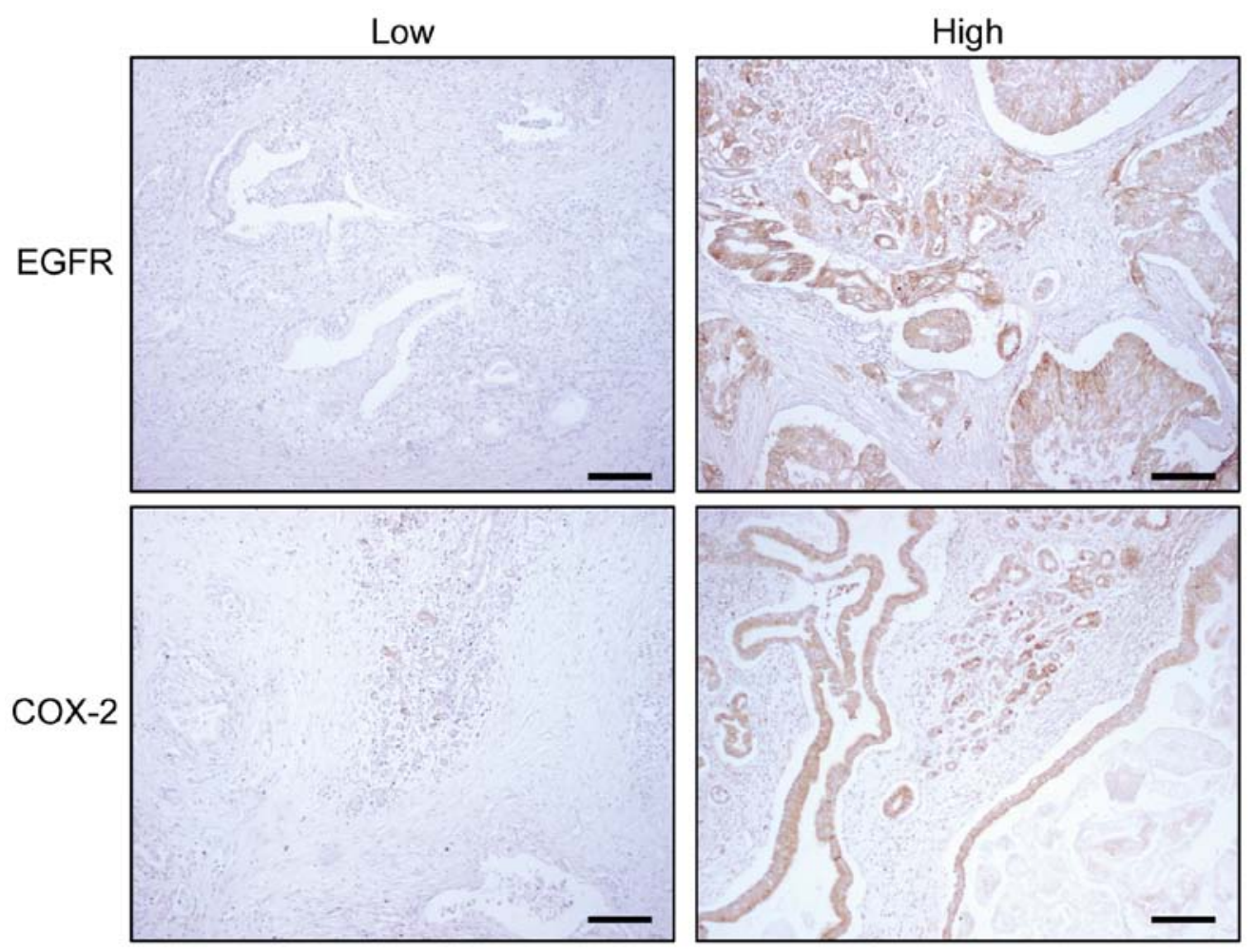

Figure 1. Immunohistochemistry staining of EGFR and COX-2 in pancreatic ductal adenocarcinoma tissue. Representative photomicrographs demonstrating low (left-hand panels) and high (right-hand panels) grade of membranous EGFR and cytoplasmic COX-2 expression in tumor cells. Scale bars, $100 \mu \mathrm{m}$ (brown: Positive antibody staining, blue: Hematoxylin for nuclei staining). EGFR, epithelial growth factor receptor; COX-2, cyclooxygenase-2.

according to EGFR and COX-2 protein expression in tumor cells. The median OS for the study cohort was 22.9 months. EGFR protein expression and regional lymph node metastasis were significantly associated with survival (Fig. 3). High EGFR protein expression in tumor cells was significantly associated with shorter OS (median OS: 7.9 months vs. 39.2 months $\mathrm{P}=0.004$, Fig. 3A). In contrast, we did not detect any significant difference in median OS between patients with high COX-2 and low COX-2 protein expression in tumor cells (median OS: 22.6 months vs. 24.5 months $\mathrm{P}=0.596$, Fig. 3B). To further evaluate the association between EGFR and COX-2 protein expression, patients were divided into four groups: Low EGFR/Low COX-2; Low EGFR/High COX-2; High EGFR/Low COX-2; High EGFR/High COX-2. Analysis of OS in these groups showed that patients with high EGFR score have shorter median OS in both the Low COX-2 and High COX-2 subgroups (median OS: Low EGFR/Low COX-2=31.7 months vs. High EGFR/Low COX-2=19.9 months and Low EGFR/High COX-2=53.4 months vs. High EGFR/High COX-2=7.5 months, $\mathrm{P}=0.038$, Fig. 3C). Furthermore, median OS in patients with regional lymph node metastasis was also significantly shorter than OS in patients without regional lymph node metastasis (median OS: 21.0 months vs. 36.7 months, $\mathrm{P}=0.025$, Fig. 3D). However, the established prognostic factor tumor stage (31) was not significantly associated with survival (data not shown).

The hazard ratio (HR) for death in patients with high EGFR protein expression in tumor cells (when compared with low EGFR protein expression in tumor cells) was $3.12(95 \%$ CI: $1.39-7.00, \mathrm{P}=0.006$, Table III). The corresponding HR for regional lymph node metastasis was 2.65 (95\% CI: 1.10-6.39,
$\mathrm{P}=0.030$ ). In multivariate analysis, where regional lymph node metastasis and EGFR score were included, only high EGFR protein expression score remained as significant independent prognostic factor for overall survival ( $\mathrm{P}=0.043$, Table III).

To conclude, these results indicate that high EGFR, but not COX-2, protein expression in tumor cells is an independent prognostic factor for poor survival in resected PDAC patients.

\section{Discussion}

In this study, we demonstrated that EGFR protein expression is a prognostic factor for survival in resected PDAC patients. Patients with high EGFR protein expression in tumor cells had significantly shorter overall survival. In contrast, COX-2 protein expression was not significantly associated with clinical outcomes. Thus, EGFR seems to be a more significant predictor than COX-2 for survival in resected PDAC patients.

In agreement with previous studies, we showed that high EGFR protein expression is associated with poor survival in PDAC patients $(8,30,32,33)$. The study with the largest sample size, by Valsecchi and colleagues (30) demonstrated similarly to our study that high membrane EGFR protein expression was significantly associated with shorter overall survival. Yet, other studies have not detected any significant association $(7,34,35)$. A reason for these differences may be the use of different antibodies. We used an antibody that only detects wild-type EGFR, whereas many of the studies reporting no association used antibodies that detect both wild-type and a 2-7 truncated EGFR variant (EGFR-vIII). This truncated EGFR variant is the most common form of mutant EGFR and does not require ligand binding to activate downstream signaling. However, the 
Table I. Clinicopathological characteristics and EGFR status.

\begin{tabular}{|c|c|c|c|}
\hline Characteristic & $\begin{array}{l}\text { EGFR High, } \\
\text { n }(\%)\end{array}$ & $\begin{array}{l}\text { EGFR Low, } \\
\mathrm{n}(\%)\end{array}$ & P-value \\
\hline All & $15(47)$ & $17(53)$ & \\
\hline \multicolumn{4}{|l|}{ Age, years } \\
\hline$<65$ & $11(73)$ & $8(47)$ & \multirow[t]{2}{*}{$0.165^{\mathrm{b}}$} \\
\hline$\geq 65$ & $4(27)$ & $9(53)$ & \\
\hline \multicolumn{4}{|l|}{ Sex } \\
\hline Female & $7(47)$ & $8(47)$ & \multirow[t]{2}{*}{0.982} \\
\hline Male & $8(53)$ & $9(53)$ & \\
\hline \multicolumn{4}{|l|}{ Tumor location } \\
\hline Head & $13(88)$ & $16(94)$ & \multirow[t]{2}{*}{0.471} \\
\hline Others & $2(12)$ & $1(6)$ & \\
\hline \multicolumn{4}{|l|}{ Tumor stage } \\
\hline $\mathrm{T} 1$ & $3(20)$ & $0(0)$ & \multirow[t]{4}{*}{0.103} \\
\hline $\mathrm{T} 2$ & $6(40)$ & $6(35)$ & \\
\hline $\mathrm{T} 3$ & $6(40)$ & $8(47)$ & \\
\hline $\mathrm{T} 4$ & $0(0)$ & $3(18)$ & \\
\hline \multicolumn{4}{|l|}{$\begin{array}{l}\text { Regional lymph } \\
\text { node metastasis }\end{array}$} \\
\hline No & $10(67)$ & $6(35)$ & \multirow[t]{2}{*}{0.077} \\
\hline N1 & $5(33)$ & $11(65)$ & \\
\hline \multicolumn{4}{|l|}{ COX-2 } \\
\hline Low & $9(60)$ & $7(41)$ & \multirow[t]{2}{*}{0.288} \\
\hline High & $6(40)$ & $10(59)$ & \\
\hline
\end{tabular}

${ }^{\mathrm{a} C h i}$-square test, except ${ }^{\mathrm{b}}$ Mann-Whitney U test. Distribution of EGFR staining categorization according to clinicopathological characteristics. Values are presented as the number of patients and percentages (in parentheses). EGFR, epidermal growth factor receptor; EGFR Low, EGFR staining grade low; EGFR High, EGFR staining grade high; N0/N1, no presence/presence of regional lymph node metastasis; COX-2, cyclooxygenase-2.

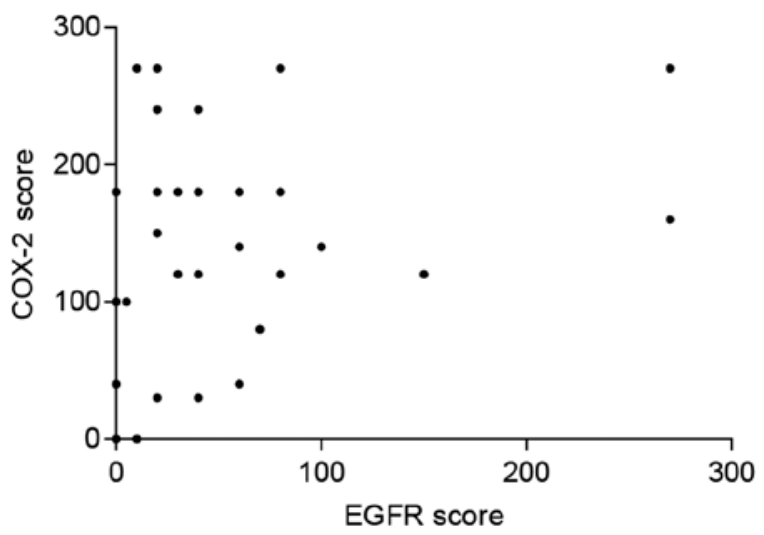

Figure 2. Correlation between EGFR and COX-2 scores. Correlation analysis revealed a positive correlation for EGFR and COX-2 protein expression in tumor cells (Spearman's rank correlation coefficient of $0.363, \mathrm{P}=0.041$. EGFR, epithelial growth factor receptor; COX-2, cyclooxygenase-2.

importance of EGFRvIII expression in PDAC is unclear (36). Therefore, conclusions about the prognostic value of EGFR
Table II. Clinicopathological characteristics and COX-2 status.

\begin{tabular}{|c|c|c|c|}
\hline Characteristic & $\begin{array}{c}\text { COX-2 } \\
\text { Low, n }(\%)\end{array}$ & $\begin{array}{c}\text { COX-2 } \\
\text { High, n }(\%)\end{array}$ & P-value ${ }^{a}$ \\
\hline All & $16(50)$ & $16(50)$ & \\
\hline \multicolumn{4}{|l|}{ Age, years } \\
\hline$<65$ & $10(63)$ & $9(56)$ & \multirow[t]{2}{*}{$0.468^{\mathrm{b}}$} \\
\hline$\geq 65$ & $6(37)$ & $7(44)$ & \\
\hline \multicolumn{4}{|l|}{ Sex } \\
\hline Female & $7(44)$ & $8(50)$ & \multirow[t]{2}{*}{0.723} \\
\hline Male & $9(56)$ & $8(50)$ & \\
\hline \multicolumn{4}{|l|}{ Tumor location } \\
\hline Head & $14(88)$ & $15(94)$ & \multirow[t]{2}{*}{0.544} \\
\hline Others & $2(12)$ & $1(6)$ & \\
\hline \multicolumn{4}{|l|}{ Tumor stage } \\
\hline $\mathrm{T} 1$ & $1(6)$ & $2(13)$ & \multirow[t]{4}{*}{0.813} \\
\hline $\mathrm{T} 2$ & $6(38)$ & $6(38)$ & \\
\hline T3 & $8(50)$ & $6(38)$ & \\
\hline $\mathrm{T} 4$ & $1(6)$ & $2(13)$ & \\
\hline \multicolumn{4}{|c|}{$\begin{array}{l}\text { Regional lymph } \\
\text { node metastasis }\end{array}$} \\
\hline No & $8(50)$ & $8(50)$ & \multirow[t]{2}{*}{1.000} \\
\hline N1 & $8(50)$ & $8(50)$ & \\
\hline \multicolumn{4}{|l|}{ EGFR } \\
\hline Low & $9(56)$ & $6(37)$ & \multirow[t]{2}{*}{0.288} \\
\hline High & $7(44)$ & $10(63)$ & \\
\hline
\end{tabular}

${ }^{\mathrm{a}}$ Chi-square test, except ${ }^{\mathrm{b}}$ Mann-Whitney $\mathrm{U}$ test. Distribution of COX-2 staining categorization according to clinicopathological characteristics. Values are presented as the number of patients and percentages (in parentheses). COX-2, cyclooxygenase-2; COX-2 Low, COX-2 staining grade low; COX-2 High, COX-2 staining grade high; N0/N1, no presence/presence of regional lymph node metastasis; EGFR, epidermal growth factor receptor.

should be drawn with caution. However, recent studies have given a better insight into the biology of EGFR-mediated signaling in PDAC and suggest a critical role for EGFR in development of PDAC. Ardito et al (13) and Navas et al (14) knocked out Egfr in KRAS-mutated mice and found that loss of EGFR completely blocked pre-malignant lesion development. Together, these studies support that EGFR is important for KRAS-driven pancreatic tumorigenesis. Since most PDAC carry KRAS mutations (37), EGFR activation is likely to be crucial also in the pathogenesis of human PDAC as it increases aggressiveness of the tumors $(32,38)$ and causes shorter survival as shown in this and previous studies.

Our results on COX-2, showing no significant association between high protein expression and overall survival, confirmed those obtained by others $(16,19-22)$. However, two more recent studies by Juuti et al (17) and Matsubayashi et al (18) demonstrated significant effects of COX-2 overexpression and clinical outcomes in PDAC patients. These studies included more patients than our study (128 and 299 patients), which may be one reason explaining the differing results. Another 
A

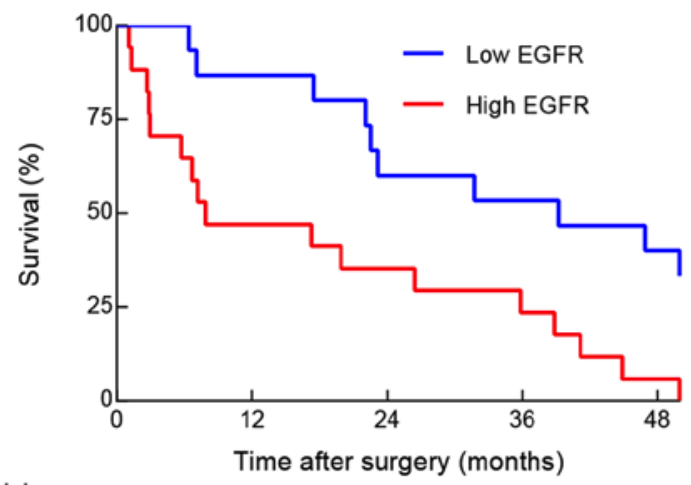

No. at risk

Low EGFR

High EGFR

$\begin{array}{lllll}15 & 13 & 9 & 8 & 6 \\ 17 & 8 & 6 & 4 & 1\end{array}$

C

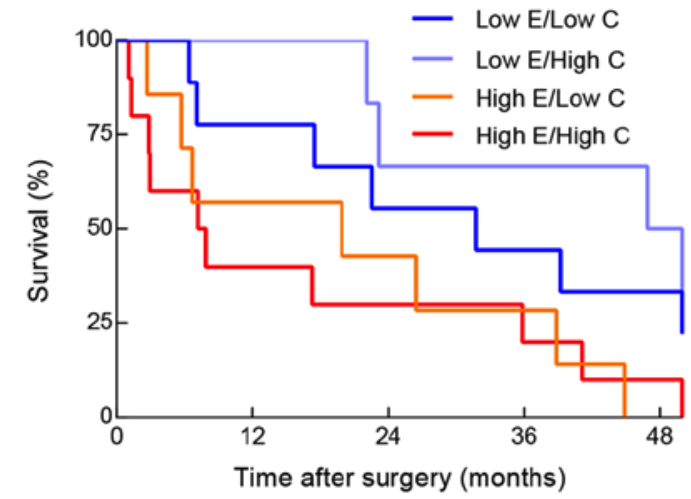

B

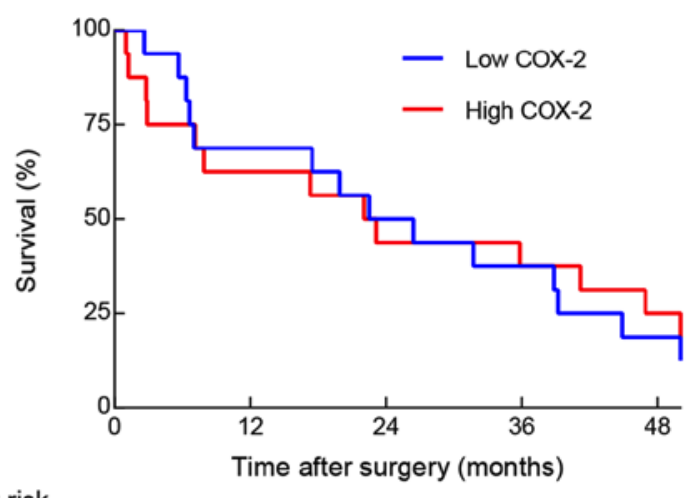

\section{No. at risk}

$\begin{array}{llllll}\text { Low COX-2 } & 16 & 11 & 8 & 6 & 3\end{array}$
D

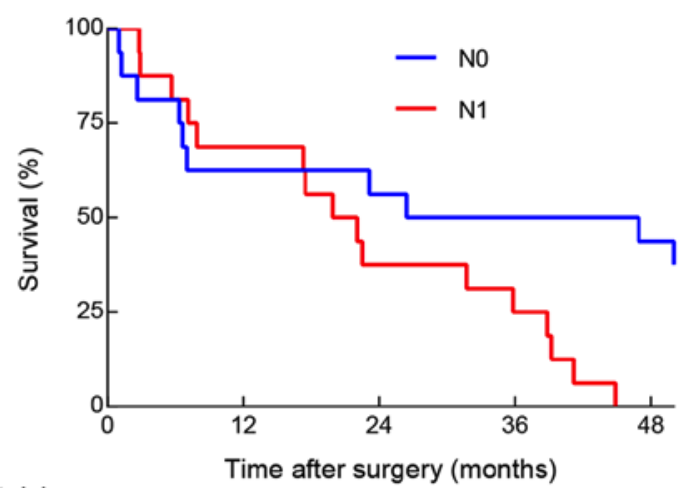

No. at risk NO $\quad 16$ N1 $\quad 16$

Time after surgery (months)

$\begin{array}{lllll}16 & 10 & 9 & 8 & 7 \\ 16 & 11 & 8 & 4 & 0\end{array}$

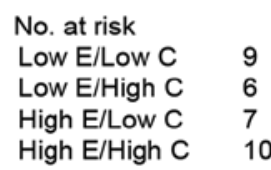

$\begin{array}{llll}7 & 5 & 4 & 3 \\ 6 & 4 & 4 & 3 \\ 4 & 3 & 2 & 0 \\ 4 & 3 & 2 & 1\end{array}$

Figure 3. EGFR and regional lymph node metastasis are significant prognostic factors for survival. Kaplan-Meier analysis of overall survival following resection with curative intent for PDAC according to (A) EGFR score ( $\mathrm{P}=0.004)$, (B) COX-2 score (P=0.596), (C) subgroup analysis of EGFR score (termed E) status in COX-2 score (termed $\mathrm{C}$ ) Low and High groups $(\mathrm{P}=0.038)$, and $(\mathrm{D})$ regional lymph node metastasis. N0/N1, no presence/presence of regional lymph node metastasis $(\mathrm{P}=0.025$; log rank test). EGFR, epithelial growth factor receptor; COX-2, cyclooxygenase-2.

reason could be the use of different antibodies (39). Yet another reason may be differences in the evaluation of the IHC staining. We used a histoscore system, where staining intensity and percentage of tumor cells showing positive staining were assessed separately before combined into a staining score, in which relatively more weight is given to higher-intensity staining in a given tumor sample.

A link between EGFR and COX-2 signaling pathways has been suggested in some cancers, mainly in experimental studies of colorectal cancer and head and neck cancer, where EGFR upregulates COX-2 or vice versa $(26,27)$. For PDAC, a recent study by Hu et al (40) using PDAC cell lines reported that EGFR and COX-2 are linked and that overactive EGFR signaling leads to overexpression of COX-2 and subsequent secretion of VEGF, promoting angiogenesis which contribute to PDAC tumor cell growth. However, there is no support in the literature for such an association in human PDAC. Although we found a weak positive correlation between EGFR and COX-2 score, this potential link between the signaling pathways will require further mechanistic studies in appropriate experimental models.

The results presented in this study, suggest that EGFR is a superior predictor of survival than COX-2 since only EGFR score in tumor cells was shown to be a prognostic factor. To our knowledge, there is only one previous study that has examined the relationship between both EGFR and COX-2 tumor expression and survival among pancreatic cancer patients in the same study. Lozano-Leon and colleagues (41) reported no significant associations between EGFR or COX-2 expression and survival. In contrast to our study, where we used whole tissue sections, they performed IHC on tissue microarrays, which may have its limitations in survival analysis in small patient materials and when the number of tumor cores is limited (42).

A limitation of our study is the small number of patients. This may explain why we did not find a significant association between an established prognostic factor such as tumor stage and survival (31). However, we could still demonstrate an association between another established prognostic factor, regional lymph node metastasis, and overall survival.

As there are no effective treatments, to date, for pancreatic cancer, it is important to develop molecular biomarkers that predict clinical outcomes. This may help direct more effective targeted therapy in high-risk patients such as patients with EGFR protein overexpression in their tumors. Since the EGFR inhibitor, erlotinib, is already in clinical use in combination with gemcitabine for unresectable locally advanced or metastatic PDAC $(9,10)$, there should be no restrictions as to 
Table III. Prognostic factors of overall survival in 32 patients with pancreatic ductal adenocarcinoma following resection.

\begin{tabular}{|c|c|c|c|c|c|c|}
\hline \multirow[b]{2}{*}{ Variable } & \multicolumn{3}{|c|}{ Univariate analysis } & \multicolumn{3}{|c|}{ Multivariate analysis ${ }^{\mathrm{a}}$} \\
\hline & HR & $95 \% \mathrm{CI}$ & P-value & HR & $95 \% \mathrm{CI}$ & P-value \\
\hline \multicolumn{7}{|c|}{ Age, years } \\
\hline$<65$ & 1 & $0.62-2.71$ & 0.487 & & & \\
\hline$\geq 65$ & 1.30 & & & & & \\
\hline \multicolumn{7}{|l|}{ Sex } \\
\hline Female & 1 & $0.43-1.78$ & 0.701 & & & \\
\hline Male & 0.87 & & & & & \\
\hline \multicolumn{7}{|c|}{ Tumor location } \\
\hline Head & 1 & $0.46-5.19$ & 0.480 & & & \\
\hline Others & 1.55 & & & & & \\
\hline \multicolumn{7}{|c|}{ Tumor stage } \\
\hline $\mathrm{T} 1-2$ & 1 & $0.38-1.60$ & 0.491 & & & \\
\hline $\mathrm{T} 3-4$ & 0.78 & & & & & \\
\hline \multicolumn{7}{|c|}{ Regional lymph node metastasis } \\
\hline N0 & 1 & $1.10-6.39$ & 0.030 & 1 & $0.66-4.48$ & 0.267 \\
\hline N1 & 2.65 & & & 1.72 & & \\
\hline \multicolumn{7}{|l|}{ EGFR } \\
\hline Low & 1 & $1.39-7.00$ & 0.006 & 1 & $1.03-6.15$ & 0.043 \\
\hline High & 3.12 & & & 2.52 & & \\
\hline \multicolumn{7}{|l|}{ COX-2 } \\
\hline Low & 1 & $0.59-2.51$ & 0.596 & & & \\
\hline High & 1.22 & & & & & \\
\hline
\end{tabular}

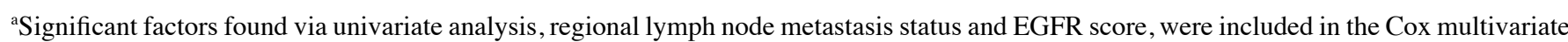
model. Univariate and multivariate Cox proportional hazards regression analysis. HR, hazard ratio; CI, confidence interval; N0/N1, no presence/presence of regional lymph node metastasis; EGFR, Epidermal growth factor receptor; COX-2, cyclooxygenase-2.

consider evaluations of EGFR-targeted therapy for resected PDAC patients. Our work underscores the importance of biomarkers, such as wild-type EGFR, for identifying patients for inclusion in large randomized studies.

In conclusion, our results show that high wild-type EGFR protein expression, but not COX-2 protein expression, in tumor cells is a prognostic factor for reduced survival following pancreatic tumor resection. This supports a role for wild-type EGFR as a biomarker in identifying resected PDAC patients that may benefit the most from EGFR-targeted therapy.

\section{Acknowledgements}

Not applicable.

\section{Funding}

The present research was supported by grants from the Swedish Cancer Society (grant nos. CAN 2015/400 and 2017/401), Sahlgrenska Academy (grant no. V 2012/294), Assar Gabrielsson's and Lundgren's Foundations (grant nos. 2017-1691 and 2018-2314).

\section{Availability of data and materials}

The datasets used and/or analyzed during the current study are available from the corresponding author on reasonable request.

\section{Authors' contributions}

DL and PF performed the experiments. DL, CE and JBF analyzed the data and performed the statistical analyses. DL, PF, BMI, KL and JBF conceived the study and designed the experiments. PN, KL and JBF interpreted data and revised the manuscript critically for important intellectual content. All authors read, reviewed and approved the final manuscript.

\section{Ethics approval and consent to participate}

Human pancreatic tumor tissue sections were obtained from the Pathology Department at Sahlgrenska University Hospital (Gothenburg, Sweden). The present study was approved by the Regional Ethical Review Board in Gothenburg, Sweden (reference no. 002-06) and all participants gave written informed consent. 


\section{Patient consent for publication}

Not applicable.

\section{Competing interests}

The authors declare that they have no competing interests.

\section{References}

1. Hezel AF, Kimmelman AC, Stanger BZ, Bardeesy N and Depinho RA: Genetics and biology of pancreatic ductal adenocarcinoma. Genes Dev 20: 1218-1249, 2006.

2. Siegel RL, Miller KD and Jemal A: Cancer statistics, 2018. CA Cancer J Clin 68: 7-30, 2018.

3. Hishinuma S, Ogata Y, Tomikawa M, Ozawa I, Hirabayashi K and Igarashi S: Patterns of recurrence after curative resection of pancreatic cancer, based on autopsy findings. J Gastrointest Surg 10: 511-518, 2006.

4. Iacobuzio-Donahue CA, Fu B, Yachida S, Luo M, Abe H, Henderson CM, Vilardell F, Wang Z, Keller JW, Banerjee P, et al DPC4 gene status of the primary carcinoma correlates with patterns of failure in patients with pancreatic cancer. J Clin Oncol 27: 1806-1813, 2009

5. Philip PA and Lutz MP: Targeting epidermal growth factor receptor-related signaling pathways in pancreatic cancer. Pancreas 44: 1046-1052, 2015.

6. Tobita K, Kijima H, Dowaki S, Kashiwagi H, Ohtani Y, Oida Y, Yamazaki H, Nakamura M, Ueyama Y, Tanaka M, et al: Epidermal growth factor receptor expression in human pancreatic cancer: Significance for liver metastasis. Int J Mol Med 11: 305-309, 2003

7. Bloomston M, Bhardwaj A, Ellison EC and Frankel WL: Epidermal growth factor receptor expression in pancreatic carcinoma using tissue microarray technique. Dig Surg 23: 74-79, 2006.

8. Mahipal A, Mcdonald MJ, Witkiewicz A and Carr BI: Cell membrane and cytoplasmic epidermal growth factor receptor expression in pancreatic ductal adenocarcinoma. Med Oncol 29: 134-139, 2012.

9. Moore MJ, Goldstein D, Hamm J, Figer A, Hecht JR, Gallinger S, Au HJ, Murawa P, Walde D, Wolff RA, et al: Erlotinib plus gemcitabine compared with gemcitabine alone in patients with advanced pancreatic cancer: A phase III trial of the National Cancer Institute of Canada Clinical Trials Group. J Clin Oncol 25: 1960-1966, 2007.

10. Wang JP, Wu CY, Yeh YC, Shyr YM, Wu YY, Kuo CY, Hung YP, Chen MH, Lee WP, Luo JC, et al: Erlotinib is effective in pancreatic cancer with epidermal growth factor receptor mutations: A randomized, open-label, prospective trial. Oncotarget 6: 18162-18173, 2015.

11. Herman JM, Fan KY, Wild AT, Hacker-Prietz A, Wood LD, Blackford AL, Ellsworth S, Zheng L, Le DT, De Jesus-Acosta A, et al: Phase 2 study of erlotinib combined with adjuvant chemoradiation and chemotherapy in patients with resectable pancreatic cancer. Int J Radiat Oncol Biol Phys 86: 678-685, 2013.

12. Sinn M,Bahra M,Liersch T, Gellert K, Messmann H, Bechstein W, Waldschmidt D, Jacobasch L, Wilhelm M, Rau BM, et al: CONKO-005: Adjuvant chemotherapy with gemcitabine plus erlotinib versus gemcitabine alone in patients after R0 resection of pancreatic cancer: A multicenter randomized phase III trial. J Clin Oncol 35: 3330-3337, 2017.

13. Ardito CM, Grüner BM, Takeuchi KK, Lubeseder-Martellato C, Teichmann N, Mazur PK, Delgiorno KE, Carpenter ES, Halbrook CJ, Hall JC, et al: EGF receptor is required for KRAS-induced pancreatic tumorigenesis. Cancer Cell 22: 304-317, 2012

14. Navas C, Hernández-Porras I, Schuhmacher AJ, Sibilia M, Guerra C and Barbacid M: EGF receptor signaling is essential for k-ras oncogene-driven pancreatic ductal adenocarcinoma. Cancer Cell 22: 318-330, 2012.

15. Molina MA, Sitja-Arnau M, Lemoine MG, Frazier ML and Sinicrope FA: Increased cyclooxygenase-2 expression in human pancreatic carcinomas and cell lines: growth inhibition by nonsteroidal anti-inflammatory drugs. Cancer Res 59: 4356-4362, 1999
16. Kokawa A, Kondo H, Gotoda T, Ono H, Saito D, Nakadaira S, Kosuge $\mathrm{T}$ and Yoshida S: Increased expression of cyclooxygenase-2 in human pancreatic neoplasms and potential for chemoprevention by cyclooxygenase inhibitors. Cancer 91: 333-338, 2001.

17. Juuti A, Louhimo J, Nordling S, Ristimäki A and Haglund C: Cyclooxygenase-2 expression correlates with poor prognosis in pancreatic cancer. J Clin Pathol 59: 382-386, 2006.

18. Matsubayashi H, Infante JR, Winter J, Klein AP, Schulick R, Hruban R, Visvanathan K and Goggins M: Tumor COX-2 expression and prognosis of patients with resectable pancreatic cancer. Cancer Biol Ther 6: 1569-1575, 2007.

19. Richards NG, Rittenhouse DW, Freydin B, Cozzitorto JA, Grenda D, Rui H, Gonye G, Kennedy EP, Yeo CJ, Brody JR and Witkiewicz AK: HuR status is a powerful marker for prognosis and response to gemcitabine-based chemotherapy for resected pancreatic ductal adenocarcinoma patients. Ann Surg 252: 499-506, 2010.

20. Koshiba T, Hosotani R, Miyamoto Y, Wada M, Lee JU, Fujimoto K, Tsuji S, Nakajima S, Doi R and Imamura M: Immunohistochemical analysis of cyclooxygenase-2 expression in pancreatic tumors. Int J Pancreatol 26: 69-76, 1999.

21. Okami J, Yamamoto H, Fujiwara Y, Tsujie M, Kondo M, Noura S, Oshima S, Nagano H, Dono K, Umeshita K, et al: Overexpression of cyclooxygenase- 2 in carcinoma of the pancreas. Clin Cancer Res 5: 2018-2024, 1999.

22. Merati K, said Siadaty M, Andea A, Sarkar F, Ben-Josef E, Mohammad R, Philip P, Shields AF, Vaitkevicius V, Grignon DJ and Adsay NV: Expression of inflammatory modulator COX-2 in pancreatic ductal adenocarcinoma and its relationship to pathologic and clinical parameters. Am J Clin Oncol 24: 447-452, 2001.

23. Lipton A, Campbell-Baird C, Witters L, Harvey H and Ali S: Phase II trial of gemcitabine, irinotecan, and celecoxib in patients with advanced pancreatic cancer. J Clin Gastroenterol 44: 286-288, 2010

24. Kirane A, Toombs JE, Ostapoff K, Carbon JG, Zaknoen S, Braunfeld J, Schwarz RE, Burrows FJ and Brekken RA: Apricoxib, a novel inhibitor of COX-2, markedly improves standard therapy response in molecularly defined models of pancreatic cancer. Clin Cancer Res 18: 5031-5042, 2012.

25. Hill R, Li Y, Tran LM, Dry S, Calvopina JH, Garcia A, Kim C, Wang Y, Donahue TR, Herschman HR and Wu H: Cell intrinsic role of COX-2 in pancreatic cancer development. Mol Cancer Ther 11: 2127-2137, 2012.

26. Yang CC and Chang KW: Eicosanoids and HB-EGF/EGFR in cancer. Cancer Metastasis Rev: 23 Jun, 2018 (Epub ahead of print).

27. Wang D, Xia D and Dubois RN: The crosstalk of PTGS2 and EGF signaling pathways in colorectal cancer. Cancers (Basel) 3: 3894-3908, 2011.

28. Axelsson H, Lönnroth $\mathrm{C}$, Andersson $\mathrm{M}$ and Lundholm $\mathrm{K}$ : Mechanisms behind COX-1 and COX-2 inhibition of tumor growth in vivo. Int J Oncol 37: 1143-1152, 2010.

29. Lönnroth $C$, Andersson M, Asting AG, Nordgren S and Lundholm K: Preoperative low dose NSAID treatment influences the genes for stemness, growth, invasion and metastasis in colorectal cancer. Int J Oncol 45: 2208-2220, 2014.

30. Valsecchi ME, McDonald M, Brody JR, Hyslop T, Freydin B, Yeo CJ, Solomides C, Peiper SC and Witkiewicz AK: Epidermal growth factor receptor and insulinlike growth factor 1 receptor expression predict poor survival in pancreatic ductal adenocarcinoma. Cancer 118: 3484-3493, 2012.

31. Lim JE, Chien MW and Earle CC: Prognostic factors following curative resection for pancreatic adenocarcinoma: A population-based, linked database analysis of 396 patients. Ann Surg 237: 74-85, 2003

32. Ueda S, Ogata S, Tsuda H, Kawarabayashi N, Kimura M, Sugiura Y, Tamai S, Matsubara O, Hatsuse K and Mochizuki H: The correlation between cytoplasmic overexpression of epidermal growth factor receptor and tumor aggressiveness: Poor prognosis in patients with pancreatic ductal adenocarcinoma. Pancreas 29: e1-e8, 2004.

33. Perini MV, Montagnini AL, Coudry R, Patzina R, Penteado S, Abdo EE, Diniz A, Jukemura J and da Cunha JE: Prognostic significance of epidermal growth factor receptor overexpression in pancreas cancer and nodal metastasis. ANZ J Surg 85: 174-178, 2015. 
34. Smeenk HG, Erdmann J, van Dekken H, van Marion R, Hop WC, Jeekel $\mathrm{J}$ and van Eijck $\mathrm{CH}$ : Long-term survival after radical resection for pancreatic head and ampullary cancer: A potential role for the EGF-R. Dig Surg 24: 38-45, 2007.

35. Park SJ, Gu MJ, Lee DS, Yun SS, Kim HJ and Choi JH: EGFR expression in pancreatic intraepithelial neoplasia and ductal adenocarcinoma. Int J Clin Exp Pathol 8: 8298-8304, 2015.

36. Wang L, Wu H, Wang L, Lu J, Duan H, Liu X and Liang Z: Expression of amphiregulin predicts poor outcome in patients with pancreatic ductal adenocarcinoma. Diagn Pathol 11: 60, 2016.

37. Almoguera C, Shibata D, Forrester K, Martin J, Arnheim N and Perucho M: Most human carcinomas of the exocrine pancreas contain mutant c-K-ras genes. Cell 53: 549-554, 1988

38. Yamanaka Y, Friess H, Kobrin MS, Buchler M, Beger HG and Korc M: Coexpression of epidermal growth factor receptor and ligands in human pancreatic cancer is associated with enhanced tumor aggressiveness. Anticancer Res 13: 565-569, 1993.

39. Asting AG, Farivar A, Iresjö BM, Svensson H, Gustavsson B and Lundholm K: EGF receptor and COX-1/COX-2 enzyme proteins as related to corresponding mRNAs in human per-operative biopsies of colorectal cancer. BMC Cancer 13: 511, 2013.
40. Hu H, Han T, Zhuo M, Wu LL, Yuan C, Wu L, Lei W, Jiao F and Wang LW: Elevated COX-2 expression promotes angiogenesis through EGFR/p38-MAPK/Sp1-dependent signalling in pancreatic cancer. Sci Rep 7: 470, 2017.

41. Lozano-Leon A, Perez-Quintela BV, Iglesias-García J, Lariño-Noia J, Varo E, Forteza J and Domínguez-Muñoz JE: Ductal adenocarcinoma of the pancreas: Expression of growth factor receptors, oncogenes and suppressor genes, and their relationship to pathological features, staging and survival. Oncol Lett 2: 161-166, 2011.

42. Khouja MH, Baekelandt M, Sarab A, Nesland JM and Holm R: Limitations of tissue microarrays compared with whole tissue sections in survival analysis. Oncol Lett 1: 827-831, 2010.

This work is licensed under a Creative Commons

Attribution-NonCommercial-NoDerivatives 4.0 International (CC BY-NC-ND 4.0) License. 